\title{
Violence AND THE DANiEl TAles in A CHILdRen's Bible
}

\section{Author:}

Marius $\mathrm{Nel}^{1}$

\section{Affiliation:}

${ }^{1}$ School for Biblical Studies and Ancient Languages,

North-West University,

South Africa

\section{Correspondence to:}

Marius $\mathrm{Ne}$

e-mail:

mariusnel@als.org.za

\section{Postal address:}

School for Biblical Science and Ancient Languages, North-West University, Potchefstroom Campus, Private Bag X6001

Potchefstroom, 2520,

South Africa

\section{Keywords:}

Daniel; children's Bible

Old Testament; exegesis; violence

\section{Dates:}

Received: 22 Sep. 2008

Accepted: 19 Mar. 2009

Published: 12 Aug. 2009

How to cite this article: Nel, M., 2009, 'Violence and the Daniel tales in a children's Bible HTS Teologiese Studies/ Theological Studies 65(1), Art. \#150, 6 pages. DOI: 10.4102/hts.v65i1.150

This article is available at: http://www.hts.org.za

(C) 2009. The Authors. Licensee: OpenJournals Publishing. This work is licensed under the Creative Commons Attribution License.

\section{ABSTRACT}

Children enjoy the tales of Daniel and his three friends, whether told in Sunday school, day school, by parents or grandparents. These tales are cast essentially in violent terms. In this article a specific version of the tales in a children's Bible is analysed to show in what way violence serves as the thread that holds the tales together and to suggest that this might imply that violence is condoned, be it violence committed by God for the sake of his children or by his children for their own sakes. Through ideology, criticism and deconstruction it is shown how a socially engaged reading of the text necessitates narrators of the Daniel tales to criticise violence embedded within the Biblical text, especially when these tales are narrated to children.

\section{INTRODUCTION}

The Bible is read by believers with goodwill ascribed to the text. As the inspired Word of God it is seen as being filled with positive meaning. The values found in the text are seen as values that God wants believers to aspire to. Not all values in the Bible can, however, be accepted as normative (Snyman 2007:67). Believers should be given permission and be empowered to distinguish between values described in the Bible that should be aspired to and values that should be rejected.

In modern-day South Africa, many believers base their argument that the state should reinstate the death penalty on Biblical evidence that certain crimes should be punished by death, as described in Leviticus 24:16-21 (cf. Dt 21:22; 24:16, as well as Jesus' penalty as described in Lk 23:22; Ac 13:28). The implication is that ultimate violence should be answered by ultimate violence. The same is true for arguments about corporal punishment.

Violence was part of the life and world of people living in Old Testament times. ${ }^{1}$ In fact, violence is connected in many cases to the holiness of God (Snyman 2007:69). The fact that God is by far pictured as masculine, as is also the case with most of the important figures in the Bible, paves the way for violence to be part and parcel of the contents in the Bible, as men are more prone to violence than are women (König 1992:81). Anyone violating God's holiness is punished with a violent death. Think of the story of Achan and Ai in Joshua 7, or Uzzah reaching out to stabilise the Ark of the Covenant when the oxen stumbled. 'The LORD's anger burned against Uzzah because of this irreverent act; therefore God struck him down and he died there beside the ark of God' (2 Sm 6:7; NIV).

When modern believers accept violence as a norm in the world of the Old Testament, it can easily become the norm for modern-day believers living without a historical consciousness, as happens when Muslim suicide bombers use passages in the Qur'an, based on the Jewish Bible, to condone killing for political purposes. The Bible instructs believers to act or react in the same way as described in it and in this way, violence can be perceived as God's will. Violence is therefore theologically and religiously sanctioned in our modern community already characterised by violence.

The history of Western Christianity is a chronology of violence, as for example illustrated extensively by Paczensky (2000). For instance, colonialism was justified on the same grounds as was apartheid, as a Biblical injunction to conquer 'Canaan' and capture its 'heathen' inhabitants. As late as 1905, Robert Laws, a Presbyterian missionary for the London Missionary Society, reported that violence was still being used to Christianise Africans, 'und machten noch immer von der Prügelstrafe gebrauch' (Paczensky 2000:59). Africa was luckier than North America and Australia, where the indigenous population was nearly expunged as colonialists followed the exodus model of the book of Judges (Bal 1999:318). In South Africa, a system was developed that kept the 'pure' race of Christians away from the indigenous people and the indigenous people away from possession of the land. Indigenous people comprising $90 \%$ of the population eventually owned $13 \%$ of the land (Giliomee 2007:185). Apartheid was sanctioned from the many examples of violence being described in the Old Testament for purposes of keeping the elect people of God clean and pure (Van der Watt 1987:75).

It is not necessary to describe the role that violence plays today. It is an inherent part of South African society. The statistics for the financial year 2007/08 (Beeld 2 July 2008:2) show that 18847 people (or 50 daily) were murdered, 36190 persons (or 99 daily) were raped, while 14481 robberies in homes were committed. Robberies in businesses increased by $47,4 \%$ to 9862 cases. $^{2}$

It should not be necessary to argue the case for the Christian church to take a stand against violence in any form and to take care that its exegesis of the Bible does not sanction violence (Boer 1998:3). ${ }^{3}$

\footnotetext{
1.'Early Israel was a typical, changeable political organization with ruling sheikhs, clients, and labouring constituents entangled in and
} compromised by power and fear no less than any other similar groups ...' (Coote 1990:1).

2.cf. Claasen (2000:178-190) for a responsible analysis of the interpretation of violence and violent crime in South Africa.

3.Mayson (2000:61) argues that evangelical churches with their emphasis on church growth campaigns do not concern themselves with social issues when he states that these churches have one decisive goal, namely to build church membership, and not to transform society. His conme (Mayso 2000:58) that the South Afican (1) government government is also relevant. 'It is difficult to avoid the impression that many people in the church do not think that God is up to the task of transforming South Africa' (Mayson 2000:61) 
Contemporary cultural criticism should be combined with criticism of exegetical practices (Bach 1999:394), especially insofar as the proclamation to children is concerned.

The final form of the Biblical text, which has become the public transcript in most Christian churches, cannot be accepted as the last word, because the text as we have it is an ideological product of the male ruling class in ancient Israel (West 2002:240-241). Discussion of the ideological intent of the text is problematic, as Fowl (1995:16-18; cf. also Fowl 1998:63-65) indicates. However, that violence is an accepted and acceptable part of the Biblical text, at least of the Old Testament, is a given and this leads to the precondition that the modern exegete sensitised to the destructive results of violence should read against the grain of the text (West 2002:241). ${ }^{4}$ Fowl (1995:32) argues that if we find that the conventional reading of a text helps to underwrite for instance racism, exegetes should offer a counter-reading that resists racism. The same applies for instance to the curse of Ham in Genesis 9:23-26, which is used to justify slavery.

The mere offering of a counter-reading does not automatically lead to the elimination of negatives in the Biblical text. There are more things underwriting the negative elements than Biblical interpretation, and in many instances the Bible is being used to justify deeply held convictions of a community.

However, it remains necessary that exegetes should endeavour to show how specific social, political, material and theological influences and conflicts shape and were shaped by the interpretation of particular Biblical texts at particular points in time in order to speak about the various relationships between specific ideologies, the production and interpretation of texts and the practices underwritten by such interpretation in particular contexts (Fowl 1995:33). This would eventually lead to the opening up of spaces for the Bible to shape and be shaped by alternative political arrangements. Fowl (1998:78) emphasises the responsibility of the reader of the Bible to ensure vigilant self-reflection in order to enable believers to focus their attention on God. ${ }^{5}$

West (2002:243) affirms that the Christian church may not allow dominant forces of today, be they reactionary and right-wing national governments or movements, military dictatorships, transnational corporations or more local (usually male) forms of the forces of control to plunder the Bible for their own (plundering) ends, even if much of the Bible leans in their direction. ${ }^{6}$

Ideologically ingrained texts should be read very carefully in a close and more nuanced manner (West 2002:245). An important way to do this is through a sort of ideological criticism which argues that the texts of the Bible contain various ideologies that must be vigilantly exposed and resisted (Fowl 1998:95-96). ${ }^{7}$

\section{VIOLENCE AND THE OLD TESTAMENT}

\section{The problem of a definition of violence}

Violence is difficult to define, as can be seen from the difference in definitions from disciplines such as psychology, sociology, political science, ethics, philosophy and social work (Wellman 1975:5). Violence has been defined as illicit power (Ballard

\footnotetext{
4.cf. however Loader 1975 for a discussion of power granted by God to individuals in the Biblical text and requiring the responsible use thereof, e.g. 1975:360.
}

5.Fowl (1998:77-78) discusses Luke 11:34-35 to show how a body of believers is to read and perform Scripture in ways that do not simply underwrite and replicate sinful actions.

6. The current debate (middle of 2008) surrounding the pronouncements, first of Julius Malema of the ANC Youth League and then Zwelinzima Vavi of Cosatu, that they would kill if Zuma is convicted and found guilty in the fraud case against him, makes the whole debate about violence and the role of powers and powers-to-be in South Africa very relevant.

7.Fowl (1998:96) then argues that interpretation of Scripture should not be directed at the ideology supposed to lie behind the Scripture but rather at the individuals and communities interpreting Scripture.
1979:5) or the unnecessary, excessive, hurtful, offensive and unlawful use of power (Ballard 1979:6). It is the use of extreme power to hurt another person because the worth of that person is not respected (Wellman 1975:8).

The most common word used in the Old Testament for violence is hāmās. Counterparts of the Hebrew hāmās in other texts are all concerned with justice (Stoebe 1997:437), as is also the case in the Old Testament (Stoebe 1997:584-587).

Hāmās is being used in five semantic domains or spheres of meaning: It is used to describe sin or injustice, to describe physical violence, in a judicial context, within the problem of theodicy, and to describe structural violence within the community (as described by Swart, cited in Snyman 1990:320).

The primary context is human relations within a community where people treat each other unjustly, where people discriminate against each other, accuse each other falsely and judge unfairly, and where they oppress, abuse and rape each other (Etzioni 1976:679-680).

Prophetic diction often uses šōd (misdeed, destruction) as a synonym for hāmās. Religious and profane usage cannot be distinguished because hāmās always violates an order established or guaranteed by God (Stoebe 1997:437). Hāmās may indeed have originally meant the misdeed that objectively burdens the land, disturbing its relationship and its inhabitants' relationship with God (Stoebe 1997:438). If the land is full of hāmās, then the consequences for its inhabitants are punishment and destruction (Dahlberg 1962:905). The substance of hāmās is the spilling of blood and presumably moral crimes that pollute the land and stand under the verdict of capital punishment in the law (as e.g. in Lv 20:11-18) (Stoebe 1997:438).

Hāmās characterises a diminution of another's rights and living space as the violation of duty to the neighbour and encompasses the entire range of anti-social behaviour in opposition to justice and righteousness (Stoebe 1997:439). If hāmās, paradoxically, comes from God, there is no remedy for it, as demonstrated in Job 19:7. In this way hāmās becomes an encompassing term for sin per se. Hāmās is practised not only in Israel but also by foreign nations.

The term is also used to indicate brutal exploitation of the helpless, the poor, widows, orphans and foreigners, as well as the physical abuse of women (Snyman 1990:320).

It is clear that hāmās refers to different forms of violence, which complicates a clear definition even further. It refers to physical and psychological violence, personal and structural violence, justified and unjustified violence, as well as manifest and latent violence (Etzioni 1976:679-682). Ballard (1979:13-17) refers to five forms of violence: ideological, structural, institutional, criminal and pathological. Firstly, violence will be discussed as a theological problem.

\section{Violence as a theological problem}

The Hebrew Bible contains numerous instances of violence, starting in Genesis 4 with a brother being murdered and the violent pronouncement of Lamech in Genesis 4:23-24 (McEntire 2001:248-251). The cause for the flood narrative is described in Genesis 6:11 (NIV): 'Now the earth was corrupt in God's sight and was full of violence'. And the exodus starts with Moses murdering an Egyptian supervisor, including a description of the gleeful sight of the Egyptian army being drowned and ending with the seven Canaanite nations being exterminated. ${ }^{8}$

No less than 600 cases of violence are described explicitly in the Old Testament alongside 1000 narratives describing JHWH's violence, with at least 100 cases where JHWH orders

8.That is, in one idealist tradition while another more realistic view allows that the Canaanite groups lived alongside Israel. 
the violent killing of people. ${ }^{9}$ Lohfink (1983:15) states that no other anthropological theme gets as much attention as violence in the Old Testament, '... der Teil der Bibel, dessen Auslegung uns anvertraut ist, kennt kein anderes anthropologisches Thema, das ihn so erfüllen würde wie die Gewalttat' (Schwager, cited in Snyman 1990:320).

Coote (1990:4) describes Israelite society in terms of a group of poor farmers and farm workers and their families. The main political influence over their lives was the struggle of hierarchical factions linked to outside powers. The favour of powerful men like sheikhs and headmen was required because they paid over the taxes to extortionists, estate owners, local lords and monarchs. The villager was a dependent client in a world run by patrons. Access to goods, services and opportunities depended on the friendship and personal favour of local strongmen, who related in the same way to men stronger still, and so on up the scale in a society where power and privilege determined the amount of violence needed against anybody faulting against the system (Coote 1990:21). Life was afflicted by gang warfare fostered by the patrons of these wars and sanctioned by brokers (Coote 1990:22). At the top of the scale of power were Baal and later $\mathrm{JHWH}$, the divine guardian of this enterprise and the vanquisher of his opponents through perpetual engagement in armed struggle (Coote 1990:31). In this way the Israelite community was marked by violence.

Snyman (1990:320-322) investigated the attention given by researchers to the issue of violence and found that very few theologians have given attention to the theme. Even a cursory search for articles in theological dictionaries and journals reveals that the matter is not given the attention that one could expect given its prevalence in the Old Testament. Snyman quotes Lohfink's conclusion: 'Nirgends taucht die Gewalt als grunsätzliche und alles zusammenhängend durchdringende Frage auf' (Snyman 1990:321).

Lohfink relies on the theory of René Girard who, in his groundbreaking Violence and the Sacred, suggests that violence within the primitive community was held at bay by the rituals of religious sacrifices. Violence can easily escalate within the community and even threaten the survival of the community. The way out of this self-destruction is through the ritual of sacrifices. The sacrifice serves as an imitation of what is happening within the community. All aggression is concentrated on the one who is sacrificed as a scapegoat and on whom all guilt is projected. In this way the guilt of the differing parties is atoned for and a whole community unifies against the scapegoat. Violence is terminated for the moment although it could start again at any moment, necessitating another ritual of sacrificing a scapegoat (Lohfink 1983:45-47).

\section{CHILDREN'S BIBLE AND TALES OF DANIEL}

The Children's Bible Story Book (De Graaf 1990), a Scandinavian publication republished in South Africa, has been used extensively in many homes and churches for the past two decades. It is a retelling of Biblical tales for children that is more or less true to the Biblical data even though interpretations of facts were made in some cases. It is used for purposes of this article to demonstrate in a South African context what children hear when Bible tales are related to them in order to demonstrate how violence is described without any further qualification.

In her retelling of Daniel 1, De Graaf (1990:180) mentions how King Nebuchadnezzar made the Jews into slaves and forced them to live in Babylon. The Jews were 'proud members' of God's 'chosen people' (De Graaf 1990:182).

Daniel 2 relates the Babylonian king's dream leading to his near murder of the wise men and his acknowledgement of Israel's God to know and reveal secrets concerning the future.

9.cf. the discussion of Ukpong (2001:21) of a hermeneutics of 'imprisonment of God in maleness' as the background for the role played by violence within the text.
In Daniel 3 Nebuchadnezzar, who had presumably forgotten what he had said about Daniel's God in Daniel 2, built a giant statue of gold and called this his god (De Graaf 1990:190). ${ }^{10} \mathrm{He}$ ordered everybody to fall to the ground and pray to his statue whenever they heard 'royal music' played (De Graaf 1990:190). 'Anyone who doesn't will be thrown into a blazing furnace to die' (De Graaf 1990:190). When the king's men noticed that the three friends of Daniel were not praying to the golden statue, they told the king. The three men did not worship the statue because to do so they would have broken God's law, which states that the Lord God is the only god and that his people may not make any statues and worship them. Standing before the king the three friends declared that they would never worship the king's god. 'Even if we are thrown into the blazing furnace, our God is able to save us from it' (De Graaf 1990:190).

Nebuchadnezzar 'burned with anger' (De Graaf 1990:190) and ordered his soldiers to tie up the three and to take care to make the fire seven times hotter than usual. When they eventually threw the friends into the furnace, it was so hot that the soldiers 'were the ones who died!' (De Graaf 1990:190).

In the fire the three men were no longer tied up and they were joined by a fourth man. 'Could this have been Jesus Himself, sent by his Father to comfort the three men?' asks De Graaf $(1990: 190) \cdot{ }^{11}$

When the three friends came out of the fire, the fourth man disappeared. The king responded that the Jews' God was the greatest and that He protected those who trusted in Him. 'From now on, no one is allowed to say anything bad about your God' (De Graaf 1990:190)

Daniel 6 recounts how Darius the Mede became king after Belshazzar was killed. One of the three men put in charge of the kingdom was Daniel. At this time he was a very old man.

He had served God with all his heart and mind and strength. He was a man of prayer. Daniel had seen God do mighty things. And the Lord had blessed Daniel with wisdom.

(De Graaf 1990:194)

After noticing that Daniel was better than the other two advisers, the king decided to put Daniel in charge of the entire kingdom. This led to jealousy from the other two advisers and their plotting against Daniel. It was difficult to find anything against Daniel concerning his work performance or moral standard of living, because he was irreproachable in his work and private life. Then they plotted to go to the king and ask him to sign an order declaring that the king is a god and that for the next thirty days, any man who prays to other gods must be thrown into the lions' den. The king liked the idea and signed the order.

Daniel continued to pray by kneeling at a window facing Jerusalem and praying for his people. His enemies saw him praying from the street below and informed the king. The king realised that he had been tricked. He tried to come up with a way of saving Daniel but there was nothing he could do to annul the royal decree that he had signed. When Daniel was brought before the king, the king told him that there was nothing he could do to save Daniel's life. 'I hope your God will save you' (De Graaf 1990:194). Then Daniel was thrown into the great pit with the wild lions and the hole was covered with a large stone.

The king rushed to the den early the next morning and asked, 'Daniel, servant of the living God! Has your God been able to rescue you from the lions?' (De Graaf 1990:194). Daniel answered that his God had indeed saved his life because he had done nothing wrong. The guards opened the den and pulled Daniel from it to find that there was not even a scratch on him. Then

10.This is factually incorrect. The people of the Ancient Near East did not worship statues but saw the statue as representing the god whose essence could not be contained in anything made by human hands.

11. The comment will not be discussed even though the unsustainability of the viewpoint is clear. 
the king ordered his guards to throw the men who had tricked and trapped Daniel into the lions' den. 'The evil advisers did not even reach the bottom of the pit before the lions finished them off'(De Graaf 1990:194)

The king then ordered that all people in his kingdom should respect the God of Daniel because He is the living God, his kingdom would last forever, $\mathrm{He}$ is the one who gives signs and does wonders and He saved Daniel from the power of the lions.

\section{DECONSTRUCTION}

Deconstruction is sometimes confused with an action with the intent to destroy - a negative approach to texts (Connor 1997:126). Derrida, Foucault, Lacan and the later Barthes emphasised that deconstruction does not stop with destroying relations within a text but with exposing the role(s) power plays within the text and within the system(s) exemplified by the text (Aichele et al. 1995:120). Deconstruction is not destruction but a dismantling of philosophical, cultural, political, institutional and, above all, textual structures designed to show how they were put together in the first place. Barbara Johnson (cited in Aichele et al. 1995:121) asks, "What's the bottom line?" What deconstruction does is to teach you to ask: "What does the construction of the bottom line leave out? What does it repress? ... What does it put in the margin?"'

The result is that deconstruction can never be a value-free or relativistic approach, but that it is always a process driven by the values of respect and equality in all relationships between people. According to Aichele et al. (1995:129), '... deconstruction represents a series of critical positions taken against totalizing schemes.' It follows naturally from a discontent with all abuse of power and a passion for empowering the marginalised. A theology of deconstruction is always involved socially and ethically in the community of the day. It always reads between the lines of all texts, whether written or defined by unwritten customs and habits, and does not accept the messages created by the influential as the truth without investigating its effect on the powerless. As a theology it tries to avoid being caught in the discourses of the majority and populism (Müller 2007:516).

The basis of deconstructive criticism is 'incredulity toward metanarrative' (Lyotard 1984:xxiv), resisting totalising accounts of 'reality', accounts that legitimate themselves 'with reference to a metadiscourse, such as the dialectics of Spirit, the hermeneutics of meaning, the emancipation of the rational or working subject, or the creation of wealth' (Lyotard 1984:xxiii; cf. Connor 1997:2425). Barthes (1977:71) uses the term doxa to indicate Lyotard's totalising metanarrative and paradox in the place of Lyotard's resistance to such metanarratives and describes the process as a doxa or popular opinion being formulated that becomes intolerable, leading to the postulation of a paradox. When this paradox becomes a new concretion or doxa, a new paradox becomes necessary.

One of the important results of deconstruction of narratives is that subordinate groups are conscientised (West 2002:246) by subversive acts such as poaching, pilfering and deconstructing discourses including trickster tales and satiric stories - constant reminders that all is not as controlled and hegemonic as it appears (West 2002:247).

Another result is the realisation that all forms of interpretation are an expression of power, the result of violence exercised upon the text in the act of reading, which is always an act of appropriation, a taking possession. Through the act of playing, free experimentation and endless alternatives, deconstruction protests against this hermeneutic of violence (Aichele et al. 1995:131).

Culler (1982:213-218) classifies the typical styles of deconstructive criticism in terms of five deconstructive reading strategies: a search for hierarchical binarisms; location of points of condensation; an examination of the text's difference from itself; a reading of the conflicts in the text; and attention to the marginal. Mathewson (2002:15) justly criticises Culler for what he calls a very non-deconstructive enterprise in trying to stylise deconstructive criticism that tries to describe the impossible in terms of the possible.

This article connects mainly to the fourth and fifth reading strategies, to deconstruct the various readings and interpretations of the text and by giving attention to that which traditional interpretation of a text has relegated to a marginal status, not essential to its unity. This is done in terms of the Children's Bible Story Book account of the Daniel tales.

\section{DECONSTRUCTING THE DANIEL TALES FOR CHILDREN}

The Children's Bible Story Book uses the 'secure' paradigm that the Bible is the Word of God to be interpreted by the conventions of common sense, while another paradigm for the practice of normal science emerged already a century ago that the Bible, however sublime, is a human book to be investigated with the standard assumptions that one brings to the discussion of all products of human culture (Spangenberg 1998:535-536, using the terminology of Mark Noll). The old paradigm is also called 'naive realism' or 'Scottish common sense realism' (Spangenberg 1998:557). This allows for an engaged reading of the Bible (West 1993:72-78; West 2001:597-604), where the study of the Bible is related to accepting responsibility for social transformation (West 1999:63).

The ideology of violence has been embedded within Christian theology, leading to many holy wars as well as the Crusades (Pretorius 1994:473). The ideology was partly based on texts in the Old Testament that legitimised violence. What is necessary is a cultivation of a consciousness of ideology and its dangers (Lubbe 1990:78), in order for a sound critique to expose and bring to the attention of others weak points and even harmful, not to say dangerous, elements within the text (Strydom \& Wessels 2000:13). Ideology can be defined as an organic idea system accepted by individuals and determining their perception of reality, a process of socially contingent values, interpretations and taken-for-granted knowledge that is necessary for the operation of society, and a means by which people orient themselves in their world (Strydom \& Wessels 2000:13). The perception then determines political and economic realities. The danger is that it may become a view of reality that excludes any other views; an idea system that provides final answers and claims an absolute moral commitment from individuals (Lubbe 1990:80).

An ideology consciousness can be cultivated by an acknowledgement of the relativity of own perceptions and that no individual can know the absolute truth. At the same time a balance must be found between trust in God and the human's own responsibility, while a consideration of human dignity should include all people, from all races, genders and orientations (Lubbe 1990:98).

Ideology, as knowledge, operates by means of discourse (Strydom \& Wessels 2000:14). In a children's Bible, attention should be given not only to the Bible stories but also to the values being transferred. Boys prefer the Daniel tales for the action and violence that form an integral part of the tales. If these tales are retold without qualifying and deconstructing the violent components, as in the De Graaff publication, value is given to violence in the mind of the young child. This makes the Bible a dangerous tool in the hands of the Church and parents.

Ideologies and power plays tend to go hand in hand. The attainment of a position of power requires that many people should believe that power should be granted to this position, leading to the promulgation of certain beliefs that people would regard as of value and accept as such. Remaining in power requires in many instances the obscuring of facts that keep 
followers uninformed, leading to false ideologies (Strydom \& Wessels 2000:14). Ideology criticism should be practised, also on Biblical texts, to empower supporters of positions of power to decide for themselves whether to believe the person in power. Ideology criticism entails examining the presuppositions of each ideology for its truth and usefulness. Socially engaged Biblical scholars recognise the ideological nature of the Biblical text, yet continue to interpret and appropriate the Biblical tradition. It is important for them to hold together both a hermeneutic of suspicion and a hermeneutic of trust, where on the one hand they insist that there is no innocent interpretation or interpreter, while on the other hand they believe that empowering and liberating interpretation of the Bible is still possible (West 1999:65-66).

A criticism against deconstructive reading strategies has been that it has shown little interest in historical or ethical matters, lacking an overt political framework. These strategies have, however, helped to create a climate of greater interpretive freedom (Aichele et al. 1995:138). It can be put to use to help transform the South African community. ${ }^{12}$

To understand the Daniel tales it is important to note that the narrator casts them in a simplified diversification between good and bad people, with Jewish believers as the good people and the heathen king and his likes as bad (Kirkpatrick 2005:42). This causes the characters to be signified as flat because no moral or other development takes place (Longman 1993:103). The purpose of the tales is to confirm that good people or believers will be the victors in the end and that bad people will receive their just penalty here and now (Kirkpatrick 2005:147). The theodicy is oversimplified.

The well-known hymn ${ }^{13}$ popular among many Sunday school children describes the purpose of the use of these tales in children's Bibles, as demonstrated by De Graaf (1990):

\section{Standing by a purpose true \\ Heeding God's command \\ Honour them the faithful few \\ All hail to Daniel's band \\ Chorus:

$$
\begin{aligned}
& \text { Dare to stand alone! } \\
& \text { Dare to have a purpose firm } \\
& \text { Dare to make it known! }
\end{aligned}
$$ \\ Dare to be a Daniel!}

Violence is used in the tales to indicate that good people will face dangers and violent treatment in their endeavours to honour God and be true to his laws. In this sense violence is only a medium to serve a bigger purpose. Nevertheless, the tales condone violence because it is not only committed by the enemy but also by the good people, and bad people are often the butts of the violence. A socially engaged exegesis of the Daniel tales for children calls for readers to look for the role played by power hunger and power plays in the tales by deconstructing the text.

The Jews, 'proud members of the chosen people' (De Graaf 1990:182), were disempowered and humiliated by the exile. They landed up in a foreign country without a king, a temple and political or economic power because of the power exercised by the mighty Babylonian king. Political power can be used to uplift people or to destroy them. It is necessary that a children's Bible should portray power for what it is, a human ability that can be used positively or negatively.

In Daniel 2, word play is used by the narrator to place the mighty king above and against the powerless magicians, with the king having power of life and death in his hands and using it to

12.'The transformation of our country requires the greatest possible cooperation between religlous and pollical bodies, crically and wisely sen held in a rolive ing of our society' (Nelson Mandela, 24 June 1977; cited in Mayson 2000:62)

13.Gospel Hymns 384, Christian Publishing Company, Roodepoort. persecute the magicians, who are unable to tell and interpret his dream. Ironically, the mighty king needs the help of the powerless magicians. Daniel receives the ability to interpret the dream successfully but this does not signify his power over the mighty king. Daniel rather places the emphasis on God, who is able to reveal secrets (Van Deventer 2003:435).

The forgetful Nebuchadnezzar of Daniel 3 orders all people to worship his god and any act of insubordination is to be punished by death. As a despot he has the power to give such orders and this lands the three friends in the furnace. The negative aspect of power is again demonstrated. De Graaf (1990:190) emphasises the trust of the three friends in God who 'is able to save us from it' (the fire).

The tale in Daniel 6 recounts plans to murder Daniel. Again this story lends itself to explain to children how power is being used by people for their own violent ends and in what way it destroys other people. Sensitivity for the way in which violence can be used by people in power is needed to demonstrate this dimension of the tales.

The way the king eventually treats Daniel's friends may lead the reader or listener to feel that (religious) justice has been served, but even then the non-negotiability of violent means should be pointed out.

\section{SYNTHESIS}

The Daniel tales are constructed to encourage religious people surviving the Antiochean persecutions to trust $\mathrm{JHWH}$ as $\mathrm{He}$ is the one who serves final justice for his people. The Syrian persecutions created a violent context against which the Daniel tales functioned. Violence serves as the golden thread that holds the tales together. In retelling the tales for children this should be emphasised if the church accepts its responsibility to help transform society. Violence should be deconstructed and the effects of it explained to the child in order to sensitise the child to the dangers inherent in all power plays.

\section{REFERENCES}

Aichele, G., Burnett, F., Castelli, E., Fowler, R., Jobling, D., Moore, S. et al., 1995, The postmodern Bible. The Bible and culture collective, Yale University Press, London.

Bach, A., 1999, 'Rereading the body politic: Women and violence in Judges 21', in A. Bach (ed.), Women in the Hebrew Bible: A reader, pp. 389-402, Routledge, New York.

Bal, M., 1999, 'Dealing/with/women: Daughters in the Book of Judges', in A. Bach (ed.), Women in the Hebrew Bible: A reader, pp. 317-335, Routledge, New York.

Ballard, P.H., 1979, A Christian perspective on violence, British Council of Churches, London.

Barthes, R., 1977, Roland Barthes by Roland Barthes, transl. R. Howard, Macmillan, London.

Boer, R., 1998, 'Western Marxism and the interpretation of the Hebrew Bible', Journal for the Study of the Old Testament 78, 3-21.

Claasen, J.J., 2000, 'Statistics, perspectives and perceptions: Interpreting crime and violence in South Africa', in C.W. Du Toit (ed.), Violence, truth and prophetic silence: Religion and the quest for a South African common good, pp. 178-190, University of South Africa, Pretoria.

Connor, S., 1997, Post modern culture: An introduction to theories of the contemporary, Blackwell, Oxford.

Coote, R.B., 1990, Early Israel. A new horizon, Fortress Press, Minneapolis.

Culler, J., 1982, On deconstruction: Theory and criticism after structuralism, Cornell University Press, Ithaca.

Dahlberg, B.T., 1962, 'Wrath of God', in G.A. Buttrick (ed.), The interpreter's dictionary of the Bible, pp. 903-908, Abingdon, Nashville.

De Graaf, A., 1990, The children's Bible story book, CUM, Vereeniging. 
Etzioni, A., 1976, 'Collective violence', in R.K. Merton \& R. Nisbet (eds), Contemporary social problems, pp. 675-726, Harcourt, New York.

Fowl, S., 1995, 'Texts don't have ideologies', Biblical Interpretation 3, 15-34.

Fowl, S.E., 1998, Engaging Scripture: Challenges in contemporary theology, Blackwell, Oxford.

Giliomee, H., 2007, 'From agrarian to industrial society (18501945)', in H. Giliomee \& B. Mbenga (eds.), New history of South Africa, pp. 184-304, Tafelberg, Cape Town.

Kirkpatrick, S., 2005, Competing for honour: A social-scientific reading of Daniel 1-6, Brill Academic, Boston.

König, A., 1992, 'Die manlikheid van God', Ned Geref Teologiese Tydskrif 33(1), 81-92.

Loader, J.A., 1975, 'Aspekte van menslike mag in die Ou Testament', Unpublished dissertation, Rijksuniversiteit te Groningen.

Lohfink, N., 1983, 'Gewalt als Thema alttestamentlicher Forschung', in E. Haag (ed.), Gewalt und Gewaltlosigkeit im Alten Testament, pp. 15-50, Herder, Freiburg.

Longman, T., 1993, 'The literature of the Old Testament', in L. Ryken \& T. Longman (eds), A complete literary guide to the Bible, pp. 95-107, Zondervan, Grand Rapids.

Lubbe, J.J., 1990, 'Ideologie en teologie. Op weg na 'n ideologiebewustheid', Acta Theologica 10(1), 78-100.

Lyotard, J-F., 1984, 'The postmodern condition: A report on knowledge', transl. G. Bennington \& B. Massumi, Theory and History of Literature 10, University of Minneapolis Press, Minneapolis.

Mathewson, D.B., 2002, 'A critical binarism: Source criticism and deconstructive criticism', Journal for the Study of the Old Testament 98, 3-28.

Mayson, C., 2000, 'Listening for the prophetic voices: Where have all the prophets gone? Prophetic silences and the incapacity of religions to take us forward', in C.W. Du Toit (ed.), Violence, truth and prophetic silence: Religion and the quest for a South African common good, pp. 55-81, University of South Africa, Pretoria.

McEntire, M., 2001, 'Cain and Abel in Africa: An Ethiopian case study in competing hermeneutics', in G.O. West \& M.W Dube (eds.), The Bible in Africa: Transactions, trajectories, and trends, pp. 248-259, Brill Academic, Boston.

Müller, J.C., 2007, 'Lente in the teologie: 'n Opwindende ligstraal van hoop vir die kerk', Verbum et Ecclesia 28(2), 509-523.
Pretorius, P.A.C., 1994, 'Die geestelike oorlog as hermeneutiese beginsel geïllustreer aan die hand van Job', Ned Geref Teologiese Tydskrif 35(4), 469-474.

Snyman, G., 1990, 'Geweld - 'n onopgeloste teologiese probleem vir die Ou Testament', Ned Geref Teologiese Tydskrif 31(3), 319_ 323.

Snyman, G., 2007, Om die Bybel anders te lees. 'n Etiek van Bybellees, Griffel, Pretoria.

Spangenberg, I., 1998, 'Op pad na 2000 - oftewel, oor al die dinge wat gebeur het', Old Testament Essays 11(3), 534-566.

Stoebe, H.J., 1997, 'hāmās violence', in E. Jenni \& C. Westermann (eds), Theological Lexicon of the Old Testament, vol. 1, 437-439, Hendrickson, Peabody.

Strydom, J.G. \& Wessels, W.J., 2000, Prophetic perspectives on power and social justice, Biblia, Pretoria.

Ukpong, J.S., 2001, 'Developments in Biblical interpretation in Africa: Historical and hermeneutical directions', in G.O. West \& M.W. Dube (eds.), The Bible in Africa: Transactions, trajectories, and trends, pp. 11-28, Brill Academic, Boston.

Van der Watt, P.B., 1987, Die Nederduitse Gereformeerde Kerk 19051975, NG Kerkboekhandel, Pretoria.

Van Deventer, H.J.M., 2003, 'Woordspel en magspel in Daniël' 2, In die Skriflig 37(3), 423-437.

Von Paczensky, G., 2000, Verbrechen in Namen Christi: Mission und Kolonialismus, Orbis, München.

Wellman, C., 1975, Morals E Ethics, Scott, Foresman \& Co., Dallas.

West, G., 1993, Contextual Bible study, Cluster, Pietermaritzburg.

West, G., 1999, The academy of the poor: Towards a dialogical reading of the Bible, vol. 2, Sheffield Academic Press, Sheffield.

West, G.O., 2001, 'Contextual Bible study in South Africa: A resource for reclaiming and regaining land, dignity and identity', in G.O. West \& M.W. Dube (eds.), The Bible in Africa: Transactions, trajectories, and trends, pp. 595-610, Brill Academic, Boston.

West, G., 2002, 'Reading abused female bodies in the Bible: Interpretative strategies for recognising and recovering the stories of women inscribed by violence but circumscribed by patriarchal text (2 Kings 5)', Old Testament Essays 15(1), 240-258. 